\title{
Receptarea actuală a unui scriitor minor, Ionel Teodoreanu
}

\author{
Drd. PANAITE Claudia-Cristina \\ Universitatea „Dunărea de Jos”, Galați
}

Resumé: Ionel Teodoreanu, le poète errant dans le roman, est un écrivant controversé dans la littérature romaine, un peu ignorant, pas trop aimé par les critiques, plutôt réprimandé qu'apprécié. Bien qu'il ait beaucoup de succès auprès du grand public, il reçoit des attaques dures de la part des critiques (Eugen Lovinescu, Pompiliu Constantinescu, Șerban Cioculescu, George Călinescu, Nicolae Manolescu), mais si on tenait compte de l'affirmation de Nichita Stănescu qui déclarait que sans la critique littéraire la littérature serait aveugle, on pourrait affirmer qu'un écrivain sans critique ne peut pas être considéré un écrivant à vrai dire. On va présenter et analyser la vision des critiques dans une perspective comparatiste, on va positionner Ionel Teodoreanu entre les avocats de la défense et les avocats de l'accusation, on va essayer une revalorisation de cet écrivain qui est resté dans l'ombre des auteurs considérés canoniques à travers le "modernisme rétro", dans le discours critique actuel de Paul Cernat.

Mots clés: modernisme rétro, revalorisation, critique, écrivain mineur, discours critique actuel.

Ajungând la momentul în care putem arăta, fiecare din nou, predilecția pe care o avem către literatură și simbolistica literaturii, ne dăm seama că am atins un anumit prag care, odată trecut, ne permite să citim astăzi cartea cu alți ochii, unii experimentați, unii care beneficiază acum de unele arme ale interpretării pe care nu le aveam odinioară. Ba mai mult, a reciti ne premite să filtrăm literatura prin anumite grile de lectură care pot uneori să schimbe statutul unui scriitor în concepția celui care reușește să realizeze o recitire detașată. Așa se întâmplă astăzi cu mulți scriitori cunoscuți sau minori. Avem ocazia să realizăm recitiri critice care să ne permită să cunoaștem cu totul și cu totul altfel vocile literare cu care credeam că suntem destul de familiarizați în trecut.

Apărută la Editura Art, colecția Revizuiri cuprinde astfel de recitiri critice. Una dintre ele este realizată lui Ionel Teodoreanu și semnată Angelo Mitchievici și Ioan Stanomir. Pe Ionel Teodoreanu îl cunoaștem cu toții pentru 
prima dată la frageda vârstă a copilăriei, ca atare, universul său literar rămâne în conștiința colectivă strâns legat de momentele de naivitate extremă, atunci când copil fiind, oricine trăiește alături de personajele din cărțile pe care le citește, întâmplări, fapte, aventuri, cutremurări, depresii sau bucurii.

Teodoreanu a rămas în mentalul colectiv drept un scriitor de copilărie, de prezența căruia ne bucurăm în primii ani ai vieții noastre, dar pe care îl uităm odată cu trecerea nemiloasă a timpului. Bunicul, Bunica sau Medelenii, apar, ca s ne încânte, dar dispar odată ce literatura serioasă își face simţită tot mai mult prezența în viețile noastre. Ceea ce îl face pe Teodoreanu un scriitor neserios? Să fie emblematicul La Medeleni o lectură simplistă, o simplă carte naivă pentru copii? Mitchievici și Stanomir doresc să demonstreze contrariul într-o lucrare dedicată acestui scriitor, Teodoreanu reloaded, lucrare care își propune aplicarea altor grile de lectură asupra paginilor autorului luat în calcul și forțarea unor schimbări de opinie în ceea ce îl privește.

Lucrarea cuprinde două părți, prima dintre ele fiind semnată Angelo Mitchievici și fiind compusă din capitolele: Medelenism și antimedelenism, Hronicul și cântecul vârstelor, Umbrele nostalgice ale Trecutului, Faruri, vitrine, cinematografii, Demonii decadenței, Avatarurile mitului: neogotic și romantism, și cealaltă, scrisă de Ioan Stanomir și intitulată sugestiv Cel din urmă basm, care cuprinde: Inventare Moldovei, De vorbă cu Ionel Teodoreanu, Arpegii, Cărarea pierdută, Strada Lăpuşneanu, Despre crepuscul și umbre, Sonata spectrelor, Intoarcerea in timp. Fiecare dintre aceste capitole este amplu dezvoltat pe mai multe subcapitole, fiecare urmărind o tematică aparte. Fără să intrăm deocamdată în detalii, putem observa că lucrarea celor doi autori urmărește să aducă scrierile lui Ionel Teodoreanu aproape de tot de grila simbolistică de lectură, aplicând valorificarea simbolurilor și hermeneutica. Ambii autori vorbesc despre două concepte fundamentale care par să pună bazele operei: medelenism și antimedelenism, concepte care dau și titlul primului capitol, semnat Angelo Mitchievici. Ce înseamnă, deci, medelenismul? Ionel Teodoreanu creează în paginile emblematicului său roman o lume aproape de basm, o atmosferă feerică, compusă din elemente care au rolul de a fascina și de a încânta lumea copilului, elemente dintre care, se aduce în prim-plan profilul casei părintești.

Casa, spațiul sacru, spațiul idilic în care locatarii casei se simt protejați și mai ales, către care tind în orice moment al vieții lor, indiferent cât de grave vor fi întâmplările prin care trec. Casa, căminul, locuința, reprezintă arhetipul axei lumii - axis mundi, centrul universului, spațiu purificator, căci de aici pornește începutul unei generații, din părinții arhaici, locatari primari ai casei. De aceea, Ulise, în timpul periplului său pe mări, supus la inimaginabile 
întâmplări și grozave pericole, nu își dorește decât un singur lucru - să se întoarcă acasă, la nevasta lui care îl așteaptă și îi rămâne fidelă și mai ales la locul care îi permite să se simtă în siguranță. Un axis mundi este, așadar, moșia La Medeleni. Și romanul lui Teodoreanu debutează cu o întoarcere, căci copiii Dănuț, Olguța și Monica - se întorc ca să-și petreacă vacanța pe moșia La Medeleni, un loc idilic, utopic.

De aici începe șirul de întâmplări pe care Ionel Teodoreanu le încarcă cu o simbolistică aparte. Însă, pentru că personajele sunt copii și pentru că în fond, nu este vorba decât despre o simplă vacanță școlară petrecută la țară, romanul nu a fost citit în grila de lectură pe care o propune hermeneutica, ci la modul naiv, luându-se în considerație strict lucrurile de suprafață, fără o alunecare în esență, atât de interesantă, dar atât de grea. Reabilitarea lui Ionel Teodoreanu pe care o propune Angelo Mitchievici propune tocmai acest lucru. $\mathrm{Nu}$ degeaba autorul își intitulează primul subcapitol: La Medeleni - hotarul nevăzut al prozei cu istoria și utopia. Am stabilit deja că întoarcerea la casa părintească, la locul sacru în care, odată pătruns, orice suflet este păzit, ferit, de influența forțelor malefice care așteaptă în lumea profană, este în fond utopia teodoresciană. Aceasta reprezintă utopia, pătrunderea într-un spațiu protector în care domnește atmosfera de basm a copilăriei pierdute și regăsite, și mai ales, în care nimic rău nu li se poate întâmpla personajelor care își trăiesc aici unele dintre cele mai frumoase și liniștite clipe ale vieții. Distopia, antimedelenismul este reprezentat de lumea de afară. Și ce fel de lume este aceea din afara moșiei Medelenilor? Una supusă războiului și factorului politic, una plină de interdicții, una care nu ar fi fost defel favorabilă unor copii, mai ales la vârsta la care se află Dănuț, Monica și Olguța cea vitează. De aceea, Ionel Teodoreanu eufemizează pentru ei războiul. În incinta casei Medelenilor, ceea ce se petrece afară este minimalizat, redus în intensitate, pentru a nu fi simțit în adevărul său cutremurător. Mitchievici aduce aici în discuție episodul din roman intitulat Potemkin și Kami-Mura. Această strategie literară nu face sub nicio formă din romanul lui Teodoranu unul minor, naiv, și nici pe scriitorul său un simplu mâzgălitor de hârtie, așa cum arată unele articole răutăcioase. Pentru a-i supraviețui și pentru a păstra spiritul copilăriei intact, Teodoreanu face din episodul istoric care a avut destul impact asupra lumii în timpul celui de-al doilea Război Mondial, o simplă teatralizare. Recunoaștem bine motivul, unul de iz romantic, și anume viața ca teatru - căci ce ar putea bagateliza un război cutremurător mai bine decât o piesă de teatru în care un asemenea eveniment ar fi redusă în intensitate de către copii? Și totuși, nimeni nu a afirmat despre romantici că ar fi simpli mâzgălitori de hârtie. Mitchievici scrie: „Istoria este pentru 
Dan Deleanu asemeni improvizației teatrale copilărești cu generalul Potemkin și generalul Kami-Mura, războiul luând o formă burlescă în interpretarea copiilor. [...] Felul in care este miniaturizat, diminutivat prin inocentare evenimentul istoric în primul roman al Medelenilolr, Hotarul nestatornic, devine emblematic pentru întreaga operă a lui Ionel Teodoreanu. Kami- Mura și generalul Potemkin există doar pentru uzul copiilor - în albumul de familie, Ionel Teodoreanu copil apare îmbrăcat în uniforma generalului japonez - asemeni soldaților confederați din plastic față în față cu indienii sioux sau navajo din același material, așezați pe o suprafață de carton gofrat. " "68

S-a atras atenția asupra bagatelizării războilui sau a evenimentelor istorice, mulți semnatari ai unor articole critice scoțând în evidență faptul că acestea, în romaul lui Ionel Teodoreanu, nu au parte de viziunea pe care o capătă, spre exemplu, în Ultima noapte de dragoste, întâia noapte de război, a lui Camil Petrescu. Și cum ar putea să o capete, când nu acesta este scopul construirii romanului Medelenilor? Să privim în ansamblu: în Ultima noapte... , Ștefan Gheorghidiu, personajul principal și erou devenit emblematic pentru literatura română suferă o dublă dramă, o dublă decepție - întâia, în dragoste, căci după o poveste frumoasă de iubire, ca toate poveștile, cu delicata Ela, constată stupefiat că femeia îl înșeală chiar atunci când el are cea mai mare nevoie de afecțiune. Ca atare, găsește de cuviință să se înroleze în război, crezând că se va aplica și pentru el mitul conform căreia războiul transformă băieții în bărbați, și că se va întoarce de acolo întărit, pregătit să lupte cu orice evenimente îi va mai pregăti viața.

Dar câmpul de luptă apare cu totul altfel decât și-ar fi imaginat el din confortul casei - ororile războiului îl zguduiesc total, mai ales când ne-a acoperit pământul lui Dumnezeu, iar în urma supraviețuirii neașteptate, Ștefan realizează că orice obstacol poate fi trecut, atâta timp cât avem o viaţă întreagă la dispoziție. Spre deosebire de alți eroi camilpetrescieni, Gheorghidiu supraviețuiește tocmai pentru că această a doua dramă, cea a războiului, una colectivă față de drama sa personală în iubire îi demonstrează că altuia i se întâmplă ceva și mai rău decât i s-a întâmplat lui, iar povestea cu Ela devine pentru el un obstacol minor, reușind în cele din urmă să se detașeze și să lase în urma sa tot trecutul.

Cum ar putea să fie comparat romanul La Medeleni, acest bilduungsroman, în fond, această emblemă a vârstei feerice a copilărie, cu poveștile cutremurătoare ale lui Gheorghidiu?! De ce ar cere cineva acest lucru?

268 Mitchievici, Angelo, Stanomir, Ioan, Teodoreanu reloaded, Editura Art, Colecția Revizitări, București, 2011, pp. 10-11 
Viziunea lui Teodoreanu face, în fond, ceea ce face orice scriitor - oferă o alternativă în fața ororilor existenței umane, dintre care războiul se evidențiază total. Medelenii înșiși sunt alternativa. Spațiul în care copiii își petrec vacanța este cu atât mai utopic cu cât amintește de un alt spațiu intens discutat de specialiștii hermeneuticii: illo tempore. Practic, odată intrați în vacanță, copiii pășesc într-un spațiu care are puterea să îi rupă de realitate, oricare ar fi ea, inclusiv de iminența și de amenințările războiului. Este vorba despre acel spațiu fără vârstă, fără naștere și moarte, spațiul paradisiac prezent în basme, căci $a$ fost odată ca niciodată... dar și în operele lui Eliade, atunci când acesta își forțează personajele să se detașeze de realitatea cotidiană și să pătrundă afară din timp și spațiu.

Este spațiul tinereții fără bătrânețe și al vieții fără de moarte, în care personajele găsesc tinerețe și fericirea, existența îndestulată și lipsită de griji, în care o simplă fundă frumos arcuită de Monica este principala grijă pentru ziua de mâine a Olguței, în care dulceața alină orice supărare, în care Moș Gheorghe nu mai contenește cu alinturile și în care cerul albastru nu este brăzdat de bombe și avioane de luptă, ci de zmee colorate, în care singura supărarea a părinților este aceea că îndrăzneața Olguța cere cafea, e o zgâtie cu Monica și îl poreclește pe Dănuț. Dincolo de toate acestea, dincolo de universul feeric și lipsit de griji planează negura deasă a realității. O realitate în care al Doilea Război Mondial își arată ghearele și atrocitățile lui Hitler ajunse la apogeu își pun amprenta asupra a zeci de ani din existența umană. Este vorba despre binomul utopie - distopie, așa cum arătat mai sus, cunoscută în basmele românești. Ieșirea din spațiul utopil înseamnă contactul cu realitatea crudă.

Așa cum prințul aflat în căutarea tinereții fără bătrânețe și vieții fără de moarte ajunge pe tărâmul în care la dispoziție ceea ce caută, dar are parte și de interdicția de a părăsi zona de comfort, așa cum el alege să-și asculte inima, să pășească dincolo purtat de naivitatea urmăririi unui iepure în timpul vânătorii și ajunge astfel în Valea plângerii, așa și personajele noastre sunt nevoite în cele din urmă să pășească în viață și să dea piept cu tot ceea ce aceasta le-a pregătit. Suferință, boală, vicii, alegeri grele, într-un cuvânt, distopie. Herr Direktor anticipează într-unul din capitolele romanului această pătrundere în viață, atunci când îi sfătuiește pe domnhul și doamna Deleanu să-și educe copiii în spiritul contactului cu lumea reală, ca aceștia să se poată descurca în viață - mai ales pe Dănuț, care ar trebui, odată și odată, să devină Dan, adică bărbat: „Nu întâmplător, unchiul junelui Deleanu, Herr Direktor, îi intruiește pe părinții acestuia să-i asigure o educație cazonă [...] să-l scoată din spațiul placentar, ombilical, al microarmoniei pentru a lua contact cu socialul, pentru a deveni bărbat, un individ 
social capabil să facă corect legăturile, să se adapteze și să răspundă provocărilor existențiale. Microarmonia vacanței aparent fără de sfârșit din spațiul Medelenilor este una înșelătoare, asemeni locului paradisiac unde absența memoriei $\hat{l}$ face pe prinț să trăiască delectabil una și aceeași clipă a unei fericiri eterne în basmul lui Ispirescu, "Tinerețe fără bătrânețe și viață fără de moarte". Dincolo însă, se află Valea plângerii, un loc care reactivează memoria și odată cu ea, timpul."269

Este evident, am putea spune, că lucrurile nu sunt atât de naive cum ne sunt prezentate într-unele dintre articolele dedicate denigrării lui Teodoreanu. Se petrece și în roman o antimedelenizare, o pătrundere în distopie, o alunecare în viață, căci odată cu maturitatea, vin grijile, nevoile și evenimentele existențiale întunecate. În spațiul lipsit de griji și memoria, în spațiul copilăriei, cunoaștem o Olguță plină de viață și pusă pe șotii, o ștrengară de care ne îndrăgostim la prima vedere și care ne impresionează cu candoarea ei.

Cunoaștem, de asemenea, o Monică frumoasă și naivă, o fetișcană blondină cu cozi împletite, al cărei singur gând este să-i împace pe cei doi frați.

Și mai cunoaștem un Dănuț, frate etern poreclit din joacă, un buftea poloboc-cioc-poc, pe care Olguța îl are tot timpul în vizor. Cine ar crede că, peste ani, Olguța, sufletul moșiei Medelenilor, își pierde viața acaparată de boală, că Monica devine o femme-fatale iar Dan-Dănuț-Deleanu, un scriitor care își forțează cariera, fiind conștient de sacrificiile pe care trebuie să le facă? Iată viața, iată zbuciumul, iată pierderea pe care autorii de articole defavorizante le tot denigrează în ceea ce privește romanul. Este vorba, în fond, despre un roman al scrierii, scriiturii și scriitorului, căci Dănuț este exponentul sacrificiilor pe care individul simplu ar trebui să le facă pentru a pătrunde în eternitate.

Da, este adevărat, moșia Medelenilor stă în picioare și există permanent, căci acolo sunt prinse sufletele de copii ale personajelor, acolo viețuiește însăși copilăria, personificată și întruchipată magistral de Olguța. Ea este sufletul moșiei. Datorită ei, farmecul primului volum nu va pieri niciodată. Dar ea este și elementul care îl împiedică pe Dănuț să devină ceea ce își dorește și simte că trebuie - scriitor. Din influență benefică, Olguța devine fantasma copilăriei care își trage prietenii înapoi. Așa că ceea ce trebuie Dănuț să facă este să o sacrifice, să o lase să plece, să se împace cu moartea ei și pe urmă, să renunțe la moșie, căci acolo Olguța va trăi veșnic. Doar o astfel de detașare va reprezenta pentru el eliberarea. Acesta este sacrificiul pe care romanticii îl considerau păcatul omului de geniu, care nu poate fi fericit pe pământ, dar nici nu poate ferici pe alții. $\mathrm{Nu}$ degeaba, un capitol din lucrarea pe care o prezentăm

${ }^{269}$ Idem, p. 14 
acum se intitulează sugestiv Avatarurile mitului:neogotic și romantism. Iată deci, detașarea și pătrunderea în universul iminent: "poate nu întâmplător este nevoie de moartea Olguței, sufletul Medelenilor, ca Dan Deleanu să se desprindă definitiv, să se desmedelenizeze iar renunțarea la a mai păstra moșia în ciuda sfatului matur al lui Herr Direktor nu ține de incapacitatea sa de a lupta pentru moșie - toți de la soție la unchiul becher și cu situație își declară susținerea - ci de o intuiție mult mai profundă, că Medelenii nu se mai află acolo. Utopia s-a destrămat. Locul nu mai are nicio importanță." 270

Cât despre personaje, lucrarea lui Mitchievici și Stanomir este dovada unei preocupări uluitoare pentru demonstrare profunzimii lor. Moartea Olguței, susțin cei doi autori, nu face decât să o proiecteze pe eroină în eternitate, alături de celelalte personaje feminine emblematice ale literaturii române - Otilia lui George Călinescu, Domnișoara Christina a lui Mircea Eliade, Irina lui Anton Holban.

În capitolul intitulat Arta portretului, avem în faţă o abordare a peronajului feminin, Olguța, în profunzimea ei.

Știm deja că fetița de odinioară este acum suferindă de cancer la sân, un cancer reactivat. Și mai știm că personajele lui Ionel Teodoreanu nu fac decât să își proiecteze existența în eternitate, prin diverse metode: Dănuț, prin maturitatea lui în arta scrierii, prin devenirea sa ca scriitor, iar Olguța, printre altele, prin pictura pe care i-o face Pallă. Portretul anticipează într-o oarecare măsură sfârșitul prematur al fetei, căci în cadrul acestuia, vivacea Olguță, ființă solară după cum spun autorii lucrării, este lipsită de orice vioiciune a ființei sale - veselia, rumeneala obrajitor, toate dispar, fiind înlocuite cu paloarea feței, cu fruntea plecată în tristețe și moarte, cu paleta sumbră și rece de culori alese de pictor mai ales în sens simbolic. Să fie acesta un semna că Olguța va deveni practic fantoma de la Medeleni? Mitchievici notează: "chipul dobândește, prin intermediul acestui ecleraj bizar, un aspect necrozat al asfixiei cu mangal, este chipul unei moarte. Pallă îi face un portret spectral Olguței, în care transpare dimensiunea melancolică a personalității sale scoase la lumină de dragostea pentru Vania, dar și prezența spectrului. O înfățișează pe Olguța la pian, însă nu cântând, nu muzica este vidul absorbant ce conferă chipului Olguței o expresie de spaimă, ci ceva ce numai ea vedee, invizibil pentru toți ceilalți [...] Privirea Olguței captează o prezență terifiantă, spectrală, se contaminează la rândul ei de această prezență angoasantă, devitalizantă." 271

\footnotetext{
${ }^{270}$ Idem, p. 15

${ }^{271}$ Idem, cap. Arta portretului - Spectroscopii nostalgice, p. 154.
} 
Și cum altfel ar putea fi, din moment ce întreaga lume feerică a basmului de odinioară se află într-un continuu proces de destrămare?

Pot spune, concluzionând, că lucrarea lui Angelo Mitchievici și Ioan Stanomir apărută la Editura Art reușește să își atingă scopul, acela de a revitaliza scrierile esențiale ale lui Ionel Teodoreanu, din care se remarcă, ca o oază de lumină lumea Medelenilor, plină de jocurile și farmecul copilăriei.

\section{BIBLIOGRAFIE:}

Mitchievici, A., Stanomir, I., Teodoreanu reloaded, Editura Art, Colecția Revizitări, București, 2011

Teodoreanu, Ionel, Masa umbrelor, Editura Forum, București, 1978

Lovinescu, Eugen, Istoria civilizației române moderne, Editura Minerva, București, 1997

Teodoreanu, Ionel, La Medeleni, volumele 1,2,3, Editura Agora, București, 1998 